\title{
An Empirical Study of Public Investors’ Financial Information Seeking Behavior in the Stock Market
}

\author{
Lin Wang ${ }^{\mathrm{a}, *}$, Baoling Ding ${ }^{\mathrm{b}}$ and Wei Liu ${ }^{\mathrm{c}}$ \\ School of Management Tianjin Normal University, China \\ a wanglinpku@163.com, bruby_101@163.com, ㄷ598767806@qq.com \\ *Corresponding Author Lin Wang
}

Keywords: Public investors, Financial information of listed companies, Investment decision-making, Information seeking behavior

\begin{abstract}
Information disclosed by listed companies such as financial statement is an important reference source for public investors to know the performance, prospect, investment value of the listed companies and make investment decisions. This paper empirically investigated the influence of years of entry and financial knowledge level on public investors' information seeking behavior. The results showed that the longer the investors enter the market and being more familiar with financial knowledge, the more likely their searches focus on the information of financial indexes such as listed companies 's earnings per share, price earnings ratio and return on assets before investment decision making. It also studied the relationship between the use frequency of information source and trust in the source. It is found that the higher degree of investors' trust in information source, the more frequently they use the source.
\end{abstract}

\section{Introduction}

After 20 years of developments, China stock market has gradually changed from emerging markets to mature market. It has attracted many enterprises to go public and sell stock to fund and financing. The stock market investors can be generally divided into institutional investors and public investors. The former mainly includes financial institutions, such as banks, insurance companies, credit cooperatives, investment trust, fund organizations established by state or group and so on. The latter can also be called individual investors or retail investors Compared with institutional investors they are the investors who engage in stock trading as a natural person, i. e., individual investors who invest in stocks, funds, bonds and other securities in the stock market. Different from institutional investors, public investors have their own characteristics as far as capital source, information source, investment motives, orientation and decision-making basis are concerned. This paper mainly studies the public investors' financial information seeking behavior. It explores the public investors' individual characteristics, information source preference, the degree of trust in information source, the degree of attention to information disclosed in the financial statements of listed companies during the information search process. It also analyzes the interrelations of the above factors.

\section{Literature Review}

Investment decision behavior of investors is regarded as an advanced cognitive process in psychology. Investors employ all kinds of available information about listed companies and the relevant information as information sources, then process, analyze and integrate the information. On the basis of these activities, they make investment decision. This process of decision-making is influenced by both information source and investors themselves. The authenticity, reliability, comprehensiveness, and timeliness of information source, and investors' age, gender, occupation, education level, years of entry, utilization degree of information source and attention to it so forth together determine the quality of decision. 
Yin and Li (2011) analyzed the relationship be tureen public investors' individual characteristics, information access pattern and risk attitude in the process of investment. The study indicated that investors' information source and their trust degree of the source have significant impacts on risk attitude of investment. Ma (2008) investigated information feature and the supply and demand mechanism in the stock market, information supply and demand relationship and discussed the characteristics of capital market information exchange. He suggested establishing an information system of the capital market. In Liu's (2004) research on public investors' information need about listed companies, he found that investors generally have the demand for the authentic, timely and sufficient disclosure of listed companies' financial information. Since investment decision-making is based on the prospect, so investors are most concerned about prospective information. $\mathrm{Li}$ and $\mathrm{Hu}$ (2012) drew a conclusion through research on selection and utilization of information source for investment: authority is a determining factor for users to choose information source. Based on the survey of the information needs of Chinese public investors, Lu (2002) pointed out the information source is mainly their acquaintances and friends. Bian (2007) studied the accounting information usage pattern of boundary rationality investors and analyzed the impact of investors' decision-usefulness view and financial information cognitive ability on investment decision-making. According to the survey of investors' accounting information need about listed companies, Wu (2000) suggested that listed companies should strengthen the disclosure of the information about human resources and financial forecast.

\section{Survey Sampling and Questionnaire Design}

This paper combines self-filling with the interview method, We distributed the questionnaire in Tianjin and Urumchi by the means of mail, interview and online survey. A total of 170 questionnaires were issued and 100 questionnaires among them were effective. The effective rate of questionnaire reached 58\%. The respondents included on service and retired individual investors or fund and bond holders, and students who hold the shares of stock, fund and bond. The occupations of in-service staff are diversified, including civil servants, staffs in state-owned enterprises, public institutions, foreign companies, private enterprises and so on.

In order to systematically survey subjects' individual characteristics, information source use frequency degree of trust in it, specific requirements of financial information disclosed by listed companies and degree of attention to financial indexes of listed companies, We reviewed researches of Yin and Li (2001), Lu and Liu (2002), Wu (2000) and Zeng and Lu (2006) and identified variables of investors' individual characteristics, capital features, experience characteristics, information seeking behavior characteristics etc. The category of information seeking behavior include the using frequency of various sources through which investors obtain listed companies' financial information, the degree of trust in information sources, specific requirements of financial information disclosed by listed companies and degree of attention to companies' financial information. Degree of attention represents the degree of investors' need for financial information, and the information need is generally regarded as independent variable of information behavior in information science and management literature. We mainly selected earnings per share, PE ratio and return on assets as listed companies' financial indexes.

We made a reliability test of items in the questionnaire. The alpha coefficient values is 0.919 , and the standard alpha coefficient values is 0.920 . The alpha coefficient value stands for the internal consistency of each item variable. The higher internal consistency they have, the better reliability of the questionnaire. In the field of behavior and social science, the reliability index of the scale should at least be above 0.6 . Reaching 0.9 means very ideal. Therefore, the reliability of our questionnaire is very good. 


\section{Research Results and Analysis}

After organizing data of 100 effective questionnaires, we used SPSS as the analysis tool for statistical analysis. We account for the analysis results in the following paragraphs.

\subsection{The influence of public investors' experience on information seeking behavior}

In order to analyze the influence of public investors' experience on their information search focus and information need, we chose years of entry and level of financial knowledge as variables to represent investors' experience. Then we chose the degree of investor's attention to listed companies' financial indexes used as variables to represent information search focus and information need. We applied hierarchical multiple regression analysis method to process data.

\subsubsection{The impact of years of entry and financial knowledge level on the degree of attention to earnings per share}

Table 1. The hierarchical regression model summary

\begin{tabular}{|l|l|l|l|l|l|}
\hline Model & $\mathrm{R}$ & $\mathrm{R}$ Square & $\begin{array}{l}\text { Adjusted } \\
\text { Square }\end{array}$ & $\mathrm{R}$ & $\begin{array}{l}\text { Std. Error of the } \\
\text { Estimate }\end{array}$ \\
\hline 1 & $.268(\mathrm{a})$ & .072 & .063 & 1.097 & \\
2 & $.359(\mathrm{~b})$ & .129 & .111 & 1.068 \\
\hline
\end{tabular}

a Predictors: (Constant), years of entry

b Predictors: (Constant), years of entry, level of financial knowledge

The results are shown in Tables 1 to 3 . We used variable of investors' years of entry and level of financial knowledge to stand for their experience and employed them as independent variables. We used the degree of attention to earnings per share (EPS) as the dependent variable. The adjusted R square values were 0.063 and 0.111 respectively. All reached significant level of 0.05 , meaning that investors' years of entry and financial knowledge level have a significant impact on the degree of attention to EPS. The variance analysis of the degree of attention to EPS was shown in Table 2.

Table 2. The regression variance analysis of the degree of attention to EPS attention degree ANOVA

\begin{tabular}{|l|l|l|l|l|l|l|}
\hline Model & & $\begin{array}{l}\text { Sum of } \\
\text { Squares }\end{array}$ & df & $\begin{array}{l}\text { Mean } \\
\text { Square }\end{array}$ & F & Sig. \\
\hline 1 & Regression & 9.153 & 1 & 9.153 & 7.612 & $.007(\mathrm{a})$ \\
& Residual & 117.847 & 98 & 1.203 & & \\
& Total & 127.000 & 99 & & & $.001(\mathrm{~b})$ \\
& Regression & 16.376 & 2 & 8.188 & 7.180 & \\
& Residual & 110.624 & 97 & 1.140 & & \\
& Total & 127.000 & 99 & & & \\
&
\end{tabular}

a Predictors: (Constant), years of entry

b Predictors: (Constant), years of entry, financial knowledge level

c Dependent Variable: the degree of attention to EPS

The F values were 7.612 and 7.180 respectively, and the P values of significant testing were 0.007 and 0.001 respectively. All are less than the significant level of 0.05 . It shows that it is statistically significant. The regression coefficient estimates values of two regression equations were shown in Table 3.

Table 3 shows that the standard estimated values of regression coefficient of EPS were 0.252 and 0.239. Sig. values were 0.009 and 0.013 . All are lower than 0.05 . Years of entry and financial knowledge level have positive impacts on the degree of attention to of EPS. Considering that collinearity may disturb regression analysis, we made a collinearity diagnosis. It was shown in collinearity statistics of table. All tolerance values were greater than 0.5 , all VIF values were less than 2. Therefore, we can claim collinearity is not a problem. 
Table 3. Regression analysis and coefficient of the degree of attention to EPS Coefficients (a)

\begin{tabular}{|c|c|c|c|c|c|c|c|c|}
\hline \multirow[b]{2}{*}{ Model } & & \multicolumn{2}{|c|}{$\begin{array}{l}\text { Unstandardized } \\
\text { Coefficients }\end{array}$} & \multirow{2}{*}{$\begin{array}{l}\text { Standardize } \\
\text { d } \\
\text { Coefficients } \\
\text { Beta }\end{array}$} & \multirow[b]{2}{*}{$\mathrm{t}$} & \multirow[b]{2}{*}{ Sig. } & \multicolumn{2}{|c|}{$\begin{array}{l}\text { Collinearity } \\
\text { Statistics }\end{array}$} \\
\hline & & $\mathrm{B}$ & $\begin{array}{l}\text { Std. } \\
\text { Error }\end{array}$ & & & & $\begin{array}{l}\text { Toleranc } \\
\mathrm{e}\end{array}$ & VIF \\
\hline \multirow[t]{2}{*}{1} & (Constant) & 3.088 & .248 & & 12.475 & .000 & & \\
\hline & $\begin{array}{l}\text { Years of } \\
\text { Entry }\end{array}$ & .297 & .108 & .268 & 2.759 & .007 & 1.000 & 1.000 \\
\hline \multirow[t]{3}{*}{2} & (Constant) & 2.224 & .420 & & 5.300 & .000 & & \\
\hline & $\begin{array}{l}\text { Years of } \\
\text { Entry }\end{array}$ & .279 & .105 & .252 & 2.656 & .009 & .995 & 1.005 \\
\hline & $\begin{array}{l}\text { Financial } \\
\text { Knowledge } \\
\text { Level }\end{array}$ & .363 & .144 & .239 & 2.517 & .013 & .995 & 1.005 \\
\hline
\end{tabular}

a Dependent Variable: the strength of attention to EPS

\subsubsection{The impact of years of entry and financial knowledge level on degree of attention to price earnings ratio}

We applied the same method to conduct a hierarchical regression analysis of degree attention to price earning PE ratio. The results are shown in Tables 4 to 6.

Table 4. The hierarchical regression model summary of degree of attention to PE ratio

\begin{tabular}{|l|l|l|l|l|l|l|}
\hline Model & $\mathrm{R}$ & R Square & $\begin{array}{l}\text { Adjusted } \\
\text { Square }\end{array}$ & $\begin{array}{l}\text { Std. Error of the } \\
\text { Estimate }\end{array}$ \\
\hline 1 & $.233(\mathrm{a})$ & .054 & .045 & 1.219 & \\
2 & $.408(\mathrm{~b})$ & .166 & .149 & 1.150 & \\
\hline
\end{tabular}

a Predictors: (Constant), years of entry

b Predictors: (Constant), years of entry, financial knowledge level

We still used variables of investors' years of entry and financial knowledge level to stand for their experience characteristics and applied these variables as independent variable. We used the degree of attention to PE ration as the dependent variable. The adjusted $\mathrm{R}$ square were 0.045 and 0.149 respectively. All reached significant level of 0.05. It means that investors' years of entry and financial knowledge level have significant impacts on the degree of attention to PE ratio.

Table 5. The regression variance analysis of degree of attention to PE ratio ANOVA(c)

\begin{tabular}{|l|l|l|l|l|l|l|}
\hline Model & & $\begin{array}{l}\text { Sum of } \\
\text { Squares }\end{array}$ & df & $\begin{array}{l}\text { Mean } \\
\text { Square }\end{array}$ & F & Sig. \\
\hline 1 & Regression & 8.340 & 1 & 8.340 & 5.611 & $.020(\mathrm{a})$ \\
& Residual & 145.660 & 98 & 1.486 & & \\
& Total & 154.000 & 99 & & & \\
2 & Regression & 25.621 & 2 & 12.811 & 9.679 & .000 (b) \\
& Residual & 128.379 & 97 & 1.323 & & \\
& Total & 154.000 & 99 & & & \\
\hline
\end{tabular}

a Predictors: (Constant), years of entry

b Predictors: (Constant), years of entry, financial knowledge level.

c Dependent Variable: Strength of attention extent of PE ratio

The $F$ values of significant testing were 5.611 and 9.679 respectively, the $P$ values of significant testing were 0.020 and 0.000 respectively, all less than the significant level of 0.05 . It shows that it is statistically significant. 
Table 6. Regression analysis and coefficient of the degree of attention to PE ratio Coefficients (a)

\begin{tabular}{|c|c|c|c|c|c|c|c|c|}
\hline \multirow[b]{2}{*}{ Model } & & \multicolumn{2}{|c|}{$\begin{array}{l}\text { Unstandardized } \\
\text { Coefficients }\end{array}$} & \multirow{2}{*}{$\begin{array}{l}\text { Standardize } \\
\text { d } \\
\text { Coefficients } \\
\text { Beta }\end{array}$} & \multirow[b]{2}{*}{$t$} & \multirow[b]{2}{*}{ Sig. } & \multicolumn{2}{|c|}{$\begin{array}{l}\text { Collinearity } \\
\text { Statistics }\end{array}$} \\
\hline & & $\mathrm{B}$ & $\begin{array}{l}\text { Std. } \\
\text { Error }\end{array}$ & & & & $\begin{array}{l}\text { Toleranc } \\
\mathrm{e}\end{array}$ & VIF \\
\hline \multirow[t]{2}{*}{1} & (Constant) & 3.016 & .275 & & 10.959 & .000 & & \\
\hline & $\begin{array}{l}\text { Years } \\
\text { Entry }\end{array}$ & .284 & .120 & .233 & 2.369 & .020 & 1.000 & 1.000 \\
\hline \multirow[t]{3}{*}{2} & (Constant) & 1.679 & .452 & & 3.715 & .000 & & \\
\hline & $\begin{array}{l}\text { Years of } \\
\text { Entry }\end{array}$ & .256 & .113 & .210 & 2.259 & .026 & .995 & 1.005 \\
\hline & $\begin{array}{l}\text { Financial } \\
\text { Knowledge } \\
\text { Level }\end{array}$ & .562 & .156 & .336 & 3.614 & .000 & .995 & 1.005 \\
\hline
\end{tabular}

a Dependent Variable: the degree of attention to PE ratio

The standard estimated value of regression coefficient of was 0.210 and 0.336 respectively. Sig. were 0.026 and 0.000 . All are lower than 0.05 . Years of entry and financial knowledge level have positive impacts on the degree of attention to $\mathrm{PE}$ ratio. The tolerance values were all greater than 0.5 and all VIF values were less than 2 . We can assert collinearity is not a problem.

\subsubsection{The degree of years of entry and financial knowledge level on degree of attention to ROA}

We applied the same method to conduct hierarchical regression analysis of degree of attention to ROA. The results are shown in Table 7 to 9.

Table 7. The hierarchical regression model summary of the degree of attention to ROA.

\begin{tabular}{|l|l|l|l|l|}
\hline Model & $\mathrm{R}$ & R Square & $\begin{array}{l}\text { Adjusted R } \\
\text { Square }\end{array}$ & $\begin{array}{l}\text { Std. Error of } \\
\text { the Estimate }\end{array}$ \\
\hline 1 & $.164(\mathrm{a})$ & .027 & .017 & 1.038 \\
2 & $.280(\mathrm{~b})$ & .079 & .060 & 1.015 \\
\hline
\end{tabular}

a Predictors: (Constant), years of entry

b Predictors: (Constant), years of entry, financial knowledge level.

We used variables of investors' years of entry and of financial knowledge level to stand for their experience characteristics and applied these variables as independent variables. We applied the degree of attention to ROA as the dependent variable. The adjusted R square values were 0.017 and 0.060 respectively. Only the variable of financial knowledge level reached a significant level of 0.05 . It means that investors' years of entry do not have a significant impact on the degree of attention to ROA, and financial knowledge level has a significant impact on the degree of attention to ROA.

Table 8. The regression variance analysis of degree of attention to ROA ANOVA(c)

\begin{tabular}{|l|l|l|l|l|l|l|}
\hline Model & & $\begin{array}{l}\text { Sum of } \\
\text { Squares }\end{array}$ & df & $\begin{array}{l}\text { Mean } \\
\text { Square }\end{array}$ & F & Sig. \\
\hline 1 & Regression & 2.928 & 1 & 2.928 & 2.718 & $.102(\mathrm{a})$ \\
& Residual & 105.582 & 98 & 1.077 & & \\
& Total & 108.510 & 99 & & & \\
2 & Regression & 8.526 & 2 & 4.263 & 4.136 & $.019(\mathrm{~b})$ \\
& Residual & 99.984 & 97 & 1.031 & & \\
& Total & 108.510 & 99 & & & \\
\hline
\end{tabular}

a Predictors: (Constant), years of entry 
b Predictors: (Constant), years of entry, financial knowledge level

c Dependent Variable: the degree of attention to ROA

The $\mathrm{F}$ values of significant testing were 2.718 and 4.136 respectively, and the values of the significant testing were 0.102 and 0.019 respectively. Therefore we only discussed the influence of financial knowledge level on the degree of attention to ROA.

Table 9. Regression analysis and coefficient of degree of attention to ROA Coefficients(a)

\begin{tabular}{|c|c|c|c|c|c|c|c|c|}
\hline \multirow[b]{2}{*}{ Model } & & \multicolumn{2}{|c|}{$\begin{array}{l}\text { Unstandardized } \\
\text { Coefficients }\end{array}$} & \multirow{2}{*}{$\begin{array}{l}\text { Standardized } \\
\text { Coefficients } \\
\text { Beta } \\
\end{array}$} & \multirow[b]{2}{*}{$\mathrm{t}$} & \multirow[b]{2}{*}{ Sig. } & \multicolumn{2}{|c|}{ Collinearity Statistics } \\
\hline & & B & Std. Error & & & & Tolerance & VIF \\
\hline 1 & $\begin{array}{l}\text { (Constant) } \\
\text { Financial } \\
\text { Knowledge } \\
\text { Level }\end{array}$ & $\begin{array}{l}2.602 \\
.334\end{array}$ & $\begin{array}{l}.357 \\
.138\end{array}$ & .238 & $\begin{array}{l}7.290 \\
2.423\end{array}$ & $\begin{array}{l}.000 \\
.017\end{array}$ & 1.000 & 1.000 \\
\hline
\end{tabular}

a Dependent Variable: degree of attention to ROA

The standard estimated value of regression coefficient was 0.238 , and sig. is 0.017 , so financial knowledge level has positive impacts on the degree of attention to ROA. According to Table 9, all tolerance values were greater than 0.5 , and all VIF less than 2 . Therefore we can assert that collinearity is not a problem.

Through the hierarchical regression analysis, we can infer that public investors' investment experience has influence on their information search focus. Years of entry and financial knowledge level all have positive impacts on investors' information need and information seeking behavior. The longer they enter into the market and the deeper financial knowledge they have, the more likely their information search focuses on the indexes of profitability, earnings-generating capacity and investment values and they have higher information need about these indexes.

\subsection{Information source utilization}

In order to understand public investors' utilization of information sources, we designed questions of information source use frequency and degree of trust in information source respectively, by using Likert-scale. We did correlation analysis of investors trust level of information source and information source use frequency. Results showed that Pearson correlation coefficient between trust level and use frequency of newspaper was 0.169, and significant level sig was 0.094, which was larger than 0.01 . This indicates the degree of correlation is not significant. As for Pearson correlation coefficients for the other four information sources: Internet media, TV media, consulting professions and personal network were $0.553,0.330,0.426$ and 0.372 respectively. All significant levels were lower than 0.01. The Pearson correlation coefficient for Internet media was greater than 0.5 , meaning moderate positive correlation. The Pearson correlation coefficients for TV, consulting professions and personal network were greater than 0.3, meaning low level positive correlation. From the results we can see that investigated investors' use frequency of information source has a significant positive correlation relationship with trust in information source. The higher trust level of information source, the higher frequency of use.

\section{Conclusion}

From the survey, we drew a conclusion that public investors years of entry and financial knowledge level have positive impacts on their degree of attention to financial information. Longer years they entered into the market and the higher financial knowledge level they have, the more likely their information search focuses on financial indexes such as earnings per share, PE ratio and ROA. As far as investors' information source utilization is concerned, investors' trust levels of information source from Internet media, TV media, personal network and consulting professions have significant positive correlations with source use frequency. The higher trust level of information source, the higher frequency of use. 


\section{Acknowledgements}

This research is financially supported by Tianjin Normal University Project "Innovative Team of Outstanding Academic Youth" and Tianjin Municipal Education Commission Project "Middle-aged Backbone Talent”.

\section{References}

[1] Baidu baike, Institutional investors .http://baike.baidu.com/view/21869.htm, 2013-03-25.

[2] Baidu baike, Individual investors. http://baike.baidu.com/view/21867.htm, 2013-03-25.

[3] Yin, H.Y. and Li, Z.M. Individual Speciality Information Acquisition and Risk Attitude Investigation and Analysis from the Chinese Stock Owners. Economic Review, 2011, 2: pp.29-37.

[4] Ma, G.Q. Analysis on Information Characteristics of Capital Market and the Mechanism of Demand \& Supply. Finance Teaching and Research, 2008,4:pp.49-54.

[5] Liu, R.M. and Zhou, L. A Study of Public Investors' Demands for Listed Companies' Information-A Survey Based on Nanjing Public Investors. Journal of Nanjing University of Finance and Economics, 2004, 4(128): pp.45-48.

[6] Li, Y.L. and Hu, L.L. Analysis of the Information Behavior of Investors: Research on the Selection and Use of Information Sources. Information and Documentation Services, 2012, 4: pp.90-97.

[7] Lu, Z.F. and Liu, G.J. An Exploration on China Private Investors' Information Demand and Decision-variable Choice. Economic Research Journal. 2002,4: pp.36-43.

[8] Bian, H. A Study on the Bounded Rational Investors' Decision Models Based on Accounting Information. Journal of Finance and Economics. 2007, 33(10): pp.61-72.

[9] Wu, L.S. A Survey and an Analysis of Investors' Demands for Listed Companies' Accounting Information. Economic Research Journal, 2000, 4: pp.41-79.

[10] Zeng, Y. and Lu, Z.F. The Relationship between Disclosure Quality and Cost of Equity Capital of Listed Companies in China. Economic Research Journal, 2006, 2: pp.69-79,91. 